\title{
Prostaglandin F2 Receptor Negative Regulator
}

National Cancer Institute

\section{Source}

National Cancer Institute. Prostaglandin F2 Receptor Negative Regulator. NCI

Thesaurus. Code C102813.

Prostaglandin F2 receptor negative regulator ( $879 \mathrm{aa}, \sim 99 \mathrm{kDa}$ ) is encoded by the human PT GFRN gene. This protein is involved in the inhibition of both prostaglandin F2-alpha binding to its receptor and any downstream signaling pathways. 